\title{
KAJIAN SIKAP DAN PERILAKU KONSUMEN DALAM PEMBELIAN KOPI SERTA PENDAPATNYA TERHADAP VARIAN PRODUK DAN POTENSI KEDAINYA
}

\author{
ELLY RASMIKAYATI ${ }^{1,2}$, PANDI PARDIAN ${ }^{1}$, HEPI HAPSARI ${ }^{1}$, RISYAD M. \\ IKHSAN $^{1}$, BOBBY RACHMAT SAEFUDIN ${ }^{2}$ \\ ${ }^{1}$ Fakultas Pertanian, Universitas Padjadjaran \\ ${ }^{2}$ Pusat Riset Pangan Berkelanjutan DRPM UNPAD \\ Email: e.rasmikayati@unpad.ac.id; elly.agri@yahoo.co.id
}

\begin{abstract}
ABSTRAK
Tingginya tingkat konsumsi kopi yang ada di Indonesia membuat peluang bagi banyak pelaku usaha kedai kopi untuk mengembangkan usahanya. Penelitian ini bertujuan untuk melihat bagaimana sikap dan perilaku konsumen terhadap pembelian kopi yang mereka lakukan di Armor Kopi Garden, Bandung. Metode analisis data yang digunakan adalah theory of reasoned action dari Fishbein yang terdiri dari sikap dan perilaku konsumen dengan sampel sebanyak 95 orang. Atribut yang digunakan dalam penelitian ini adalah rasa, variasi menu, desain produk, layanan pelengkap, harga, dan promosi. Hasil analisis menunjukkan bahwa konsumen yang datang rata-rata adalah laki-laki berstatus mahasiswa/i. Alasan mereka datang ke kedai kopi yang paling dominan adalah karena suasana yang nyaman (44\%), kemudian keinginan untuk sekedar mencoba (22\%) lalu karena faktor rasanya yang khas $(10 \%)$ dan berbagai alasan lainnya (22\%). Sikap konsumen terhadap pembelian produk kopi secara keseluruhan menunjukkan hasil yang baik. Sikap yang dianggap paling baik ada pada atribut desain produk dan yang dianggap paling tidak baik ada pada atribut promosi. Hasil analisis perilaku konsumen di Armor Kopi Garden berdasarkan angka skor rata-rata menunjukkan bahwa yang berperan paling dominan dalam membuat keputusan konsumen adalah teman dan media sedangkan skor yang terendah ada pada keluarga. Potensi yang dimiliki antara lain produk yang beragam, fasilitas yang lengkap, serta barista yang handal. Kedala yang dimiliki dalam menjalankan usaha adalah adalah adanya competitor yaitu Armor Kopi Tahura yang menyebabkan pengunjung terbagi-bagi.
\end{abstract}

Kata Kunci: kedai kopi, sikap konsumen, perilaku, pembelian produk

\section{PENDAHULUAN}

Seiring perkembangannya, masyarakat Indonesia mulai gemar meminum kopi dengan tujuan-tujuan tertentu, seperti menjaga tubuh agar tidak mengantuk saat menyetir malam atau ronda malam. Minum kopi pun biasanya hanya dilakukan oleh kelompok orangorang dewasa hingga usia lanjut dan didominasi oleh pria. Konsumsi kopi yang meningkat tiap tahunnya sudah membuat sebuah trend baru bagi masyarakat Indonesia itu sendiri. Terlihat pada data di bawah terjadi kenaikan tingkat konsumsi masyarakat akan kopi tiap tahunnya. Sebagian besar masyarakat sudah menganggap mengkonsumsi kopi bukan hanya sekedar minuman pelengkap saja tetapi melihat kopi sebagai minuman pokok sehari-hari terlebih bagi 
Kajian Sikap dan Perilaku Konsumen dalam Pembelian Kopi Serta Pendapatnya Terhadap Varian Produk dan Potensi Kedainya

ELLY R., PANDI P., HEPI H., RISYAD M.I., BOBBY R.S.

masyarakat yang sudah kecanduan akan mengkonsumsi minuman ini.

Konsumsi kopi di Indonesia telah meningkat dengan cukup pesat dari tahun-tahun sebelumnya. Hal ini diprediksi akan mengalami peningkatan seiring meningkatnya pendapatan masyarakat kelas menengah dan perubahan gaya hidup. Di bawah ini data mengenai konsumsi kopi baik arabika, robusta, dan lainnya di Indonesia terhadap pertumbuhan penduduk serta kebutuhan kopi Indonesia.

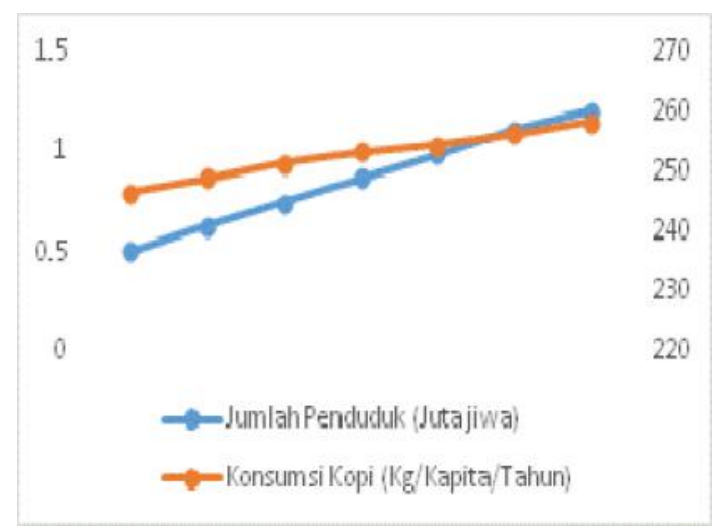

Gambar 1. Konsumsi Kopi Masyarakat Indonesia

Sumber: Asosiasi Eksportir Kopi Indonesia (AEKI), data Tahun 2014-2016 merupakan angka proyeksi

Usaha kedai kopi menjadi usaha yang menjanjikan dewasa ini. Bentuknya sangat beragam, dari kedai kopi yang terkesan eksklusif hingga kedai kopi yang standar. Kedai-kedai tersebut memiliki spesifikasi dalam menjual produknya. Saat ini, usaha kedai kopi muncul menjadi usaha yang memiliki konsep tempat, konsep jualan (marketing), konsep kemasan, konsep menu, dan konsep pelayanan yang menarik. Suasana di setiap kedai kopi yang memiliki ciri khas berbeda-beda menjadi salah satu daya tarik bagi para konsumen. Perkembangan usaha kedai kopi di Indonesia mulai marak sejak masuknya kedai kopi asal Seattle, Amerika yaitu Starbucks. Kemunculan kafe-kafe yang sukses dan memiliki pasar di Indonesia tersebut membuat banyak pelaku-pelaku usaha baru yang terinspirasi dan mulai menekuni usaha kafe atau kedai kopi. Banyak usaha-usaha kecil dan menengah berkonsep kedai, warung atau kafe kopi hingga usaha kelas besar seperti starbucks tersebar di berbagai kota-kota besar di Indonesia. Berikut data mengenai pertumbuhan coffee shop di Indonesia.

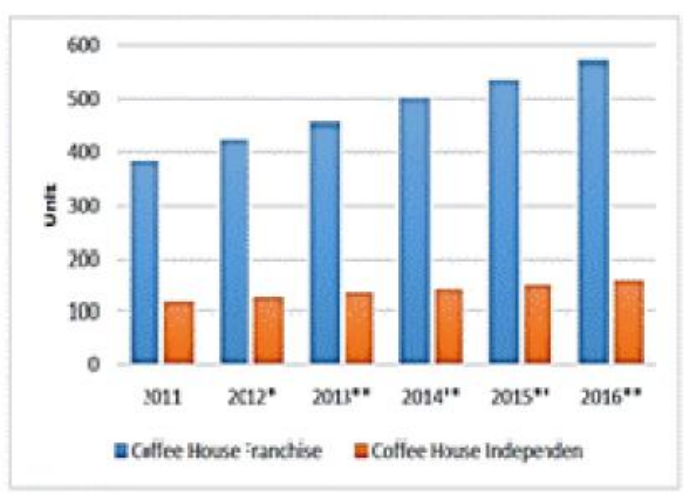

Gambar 2. Pertumbuhan Coffee Shop di Indonesia

Sumber: Euromonitor (2012), *Angka sementara $* *$ Proyeksi 
Jurnal Pemikiran Masyarakat Ilmiah Berwawasan Agribisnis. 2017. 3(2): 117-133

Berdasarkan Gambar 2 terlihat bahwa pertumbuhan coffee shop independen/lokal yang tidak kalah bersaing dengan coffee shop franchise seperti Starbucks, coffee bean, ngopi doloe, coffee toffee, bengawan solo. Tren pertumbuhan coffee shop di Indonesia menunjukkan penigkatan setiap tahunnya. Jumlah coffee shop di Indonesia diproyeksikan mengalami peningkatan dari tahun 2011 sampai 2016 sebesar 189 unit untuk coffee shop franchise dan 40 unit untuk coffee shop independen/lokal.

Salah satu kedai kopi yang berdiri di kota Bandung adalah Armor Kopi. Armor Kopi merupakan salah satu kedai kopi yang berada di Kota Bandung. Menjamurnya kedai kopi yang berada di Bandung memberikan persaingan tersendiri terhadap industri kedai kopi di Bandung. Munculnya pesaing-pesaing baru menyebabkan naik turunnya penjualan di Armor Kopi itu sendiri.

Tingginya tingkat konsumsi kopi yang ada di Indonesia membuat peluang bagi banyak pelaku usaha kedai kopi untuk mengembangkan usahanya. Salah satu kota yang banyak dihuni oleh kedai kopi adalah kota Bandung. Timbulnya pesaing yang semakin menyelaraskan bagaimana keinginan konsumen dengan produk yang mereka jual menimbulkan semakin banyaknya variasi produk yang disajikan dengan cara mereka sendiri. Oleh karena itu, konsumen menjadi selektif karena memiliki banyak pilihan untuk melakukan pembelian kopi. Berdasarkan uraian tersebut, maka tujuan penelitian adalah: (1) Mengidentifikasi karakteristik konsumen Armor Kopi; (2) Menganalisa sikap dan perilaku konsumen dalam membeli produk kopi di Armor Kopi; dan (3) Mengidentifikasi potensi dan kendala yang dimiliki Armor Kopi dalam menjalankan usahanya.

\section{TINJAUAN PUSTAKA}

\section{Sejarah Kopi dan Coffee Shop}

Kopi pertama kali ditemukan di Ethiopia pada abad ke-9 ketika seorang penggembala menyadari domba-domba gembalaannya menjadi hiperaktif setelah mengkonsumsi sejenis buah bulat berukuran kecil yang banyak tumbuh di sekitar tempatnya menggembala. Tempat asal penggembala tersebut dikenal dengan nama Kaffa, dan dari nama tempat itulah muncul istilah kopi atau coffee.

Kopi menjadi minuman yang terkenal di seluruh dunia. Dari sinilah muncul istilah kafe yang mengacu kepada kedai kopi/Cafe/ Coffee shop. Istilah kata 
Kajian Sikap dan Perilaku Konsumen dalam Pembelian Kopi Serta Pendapatnya Terhadap Varian Produk dan Potensi Kedainya

ELLY R., PANDI P., HEPI H., RISYAD M.I., BOBBY R.S.

cafe berasal dari bahasa Perancis yang berarti kopi. Orang Perancis menyebut kedai kopi dengan istilah cafe. Perancis menjadi salah satu Negara yang dijuluki "Negeri Caffe" karena pesatnya perkembangan caffe disana dan dari Perancis lah Cafe mulai tersebar luas di dunia. Cafe atau Coffee Shop atau yang di kenal sebagai Kedai Kopi berasal dari Turki (Sekarang Istanbul). Coffee Shop pertama kali berdiri di Constatinopel di Turki (Istanbul) pada tahun 1475. Pada awalnya Coffee Shop hanya menjual minuman kopi. Coffee Shop pertama di Eropa didirikan tahun 1529. Minuman ini menjadi sangat digemari di Eropa karena adanya ide untuk menyaring kopi dan memperhalus citra rasa minuman kopi dengan susu dan gula. Coffee Shop di Eropa semakin populer karena mereka tidak hanya menjual minuman kopi tetapi mulai menjual kue-kue manis dan penganan yang lainnya.

Coffee Shop pertama di Britania Inggris didirikan tahun 1652. Di Coffee Shop ini lah istilah kata "tips" pertama kali digunakan. Guna menjamin servis yang cepat, sebuah toples diletakan di meja counter, orang-orang memasukan koin tips ke toples itu untuk dapat dilayani dengan cepat. Saat ini cafel coffee shop telah tersebar ke berbagai tempat di dunia, dan bersama inipun berkembang teknik-teknik menyajikan minuman kopi.

Kopi pertama kali masuk di Indonesia pada tahun 1696 dibawa oleh Komandan Pasukan Belanda Adrian Van Ommen. Menyajikan kopi saat ini lebih dari sekedar menyeduh bubuk kopi dengan air panas lalu ditambahkan gula atau susu. Kopi bisa disajikan dengan berbagai cara. Seiring dengan berkembangnya aneka teknik pembuatan kopi, penjualan kopi pun meningkat. Kopi telah menjadi bagian hidup, khususnya bagi mereka yang tinggal di kota besar. Kopi menjadi terkenal di kalangan anak muda dan juga kalangan bisnis, sehingga harganya menjadi mahal. Hal ini yang mendorong suksesnya bisnis kedai kopi mulai dari kedai kopi sederhana yang menjual dengan harga murah hingga ke kafe-kafe elit dimana harga satu gelasnya cukup untuk membeli beberapa gelas kopi di kedai kopi sederhana. Kopi telah menjadi minuman berkelas (classy drinks). Banyak kafekafe yang mengkhususkan diri pada bisnis minuman kopi, karena konsumennya tidak pernah berkurang. Di kalangan anak muda di Indonesia, minum kopi pun telah menjadi tren (Listyari, 2006). 
Jurnal Pemikiran Masyarakat Ilmiah Berwawasan Agribisnis. 2017. 3(2): 117-133

\section{Konsumen}

Dalam penganalisisan hubungan konsumen-produk, adalah penting untuk menyadari bahwa konsumen itu beragam dalam keinginan untuk mencoba suatu produk baru. Salah satu fokus utama penelitian konsumen adalah untuk mengidentifikasi karakteristik konsumen itu sendiri. Karakteristik konsumen merupakan ciri khas dari setiap perbedaan yang terdapat dalam diri konsumen (Engel, et al, 1994). Karakteristik konsumen ini dapat digunakan oleh perusahaan dalam menentukan pasar sasarannya baik secara demografis (jenis kelamin, umur, tingkat pendidikan, pekerjaan, pendapatan dan domisili/tempat tinggal).

Karakteristik konsumen meliputi pengetahuan dan pengalaman konsumen, kepribadian konsumen dan karakteristik demografi konsumen (Sumarwan, 2003). Konsumen yang memiliki pengetahuan dan pengalaman yang banyak mengenai produk mungkin tidak termotivasi untuk mencari informasi, karena konsumen tersebut sudah merasa cukup dengan pengetahuannya untuk mengambil keputusan. Konsumen yang mempunyai kepribadian sebagai seorang yang senang mencari informasi akan meluangkan waktu untuk mencari informasi lebih banyak. Pendidikan adalah salah satu karakteristik demografi yang penting. Konsumen yang berpendidikan tinggi cenderung mencari informasi yang banyak mengenai suatu produk sebelum ia memutuskan untuk membelinya.

Memahami usia konsumen adalah salah satu faktor yang penting (Sumarwan, 2003). Oleh sebab itu, pemasar harus memahami usia penduduk dari suatu wilayah yang akan dijadikan segmentasi pasarnya. Perbedaan usia mengakibatkan perbedaan selera dan kesukaan terhadap produk. Konsumen yang berbeda usia akan mengkonsumsi produk dan jasa yang berbeda pula. Seorang yang berumur relatif muda lebih cepat menerima sesuatu yang baru, dibandingkan konsumen yang sudah berumur.

\section{Definisi Sikap}

Menurut Fishbein dan Ajzen (dalam Kristianto, 2011), sikap merupakan predisposisi (keadaan mudah terpengaruh) yang dipelajari untuk menanggapi secara konsisten terhadap suatu objek, baik dalam bentuk tanggapan positif maupun tanggapan negatif. Konsep sikap sangat berkaitan dengan konsep kepercayaan (belief) dan perilaku (behavioral). 
Kajian Sikap dan Perilaku Konsumen dalam Pembelian Kopi Serta Pendapatnya Terhadap Varian Produk dan Potensi Kedainya

ELLY R., PANDI P., HEPI H., RISYAD M.I., BOBBY R.S.

Menurut Soetarno (1994), sikap adalah pandangan atau perasaan yang disertai kecenderungan untuk bertindak terhadap obyek tertentu. Sikap senantiasa diarahkan kepada sesuatu artinya tidak ada sikap tanpa obyek.

Sikap konsumen adalah pikiran atau pandangan konsumen yang menggambarkan kepercayaan terhadap manfaat yang baik dari produk. Apabila konsumen sudah mulai percaya terhadap manfaat yang diberikan sebuah produk, maka konsumen akan bersikap untuk selalu setia dan menggunakan produk tersebut. Namun, apabila produk tersebut tidak memberikan manfaat yang baik, maka sikap konsumen adalah tidak akan mau untuk membeli dan menggunakan produk tersebut.

Dengan kata lain, sikap konsumen adalah keyakinan dan preferensi (pilihan) konsumen atas suatu merek. Sikap terhadap suatu merek yang sering mempengaruhi keputusan pembelian konsumen. Jika konsumen bersikap positif terhadap suatu merek, kemungkinan konsumen itu akan melakukan pembelian terhadap merek tersebut, begitu sebaliknya.

Katz (dalam Setiadi, 2008) mengklasifikasikan fungsi sikap menjadi empat, yaitu:
1. Fungsi utilitarian

Seseorang menyatakan sikapnya terhadap suatu objek atau produk karena ingin memperoleh manfaat dari produk (rewards) tersebut atau menghindari risiko dari produk (punishment).

2. Fungsi ekspresi nilai

Sikap berfungsi untuk menyatakan nilai, gaya hidup dan identitas sosial seseorang. Sikap akan menggambarkan minat, hobi, kegiatan, dan opini dari seorang konsumen.

3. Fungsi mempertahankan ego

Sikap berfungsi untuk melindungi seseorang (citra diri - self image) dari keraguan yang muncul dari dalam dirinya sendiri atau dari faktor luar yang mungkin menjadi ancaman bagi dirinya.

4. Fungsi pengetahuan

Pengetahuan yang baik mengenai suatu produk sering mendorong seseorang untuk menyukai produk tersebut. Karena itu, sikap positif terhadap suatu produk sering mencerminkan pengetahuan konsumen terhadap suatu produk.

Sikap memiliki beberapa karakter (Sumarwan, 2011). Karakter sikap tersebut adalah berikut ini. 
Jurnal Pemikiran Masyarakat Ilmiah Berwawasan Agribisnis. 2017. 3(2): 117-133

1. Sikap memiliki objek

Sikap konsumen harus terkait dengan objek. Objek tersebut dapat terkait dengan berbagai konsep konsumsi dan pemasaran seperti produk, merek, iklan, harga, penggunaan, dan media.

2. Konsistensi sikap

Sikap adalah gambaran perasaan dari seorang konsumen dan perasaan tersebut direfleksikan oleh perilakunya. Oleh karena itu, sikap memiliki konsistensi dengan perilaku. Perilaku seorang konsumen merupakan gambaran sikapnya.

3. Sikap positif, negatif, dan netral Seseorang mungkin menyukai (positif), tidak menyukai (negatif), atau bahkan tidak memiliki sikap (netral) terhadap suatu objek.

4. Intensitas sikap

Sikap seorang konsumen terhadap suatu merek produk akan bervariasi tingkatannya, ada yang sangat menyukainya, dan ada yang kurang suka, bahkan tidak menyukai sama sekali.

5. Resistensi sikap

Resisten adalah seberapa besar sikap seorang konsumen dapat berubah. Pemasar penting memahami bagaimana resistensi konsumen agar dapat menerapkan strategi pemasaran yang tepat. Pemasaran ofensif bisa diterapkan untuk mengubah sikap konsumen yang sangat resisten atau merekrut konsumen baru.

6. Persistensi sikap

Persistensi adalah karakteristik sikap yang menggambarkan sikap akan berubah karena berlalunya waktu.

7. Keyakinan sikap

Keyakinan adalah kepercayaan konsumen mengenai kebenaran sikap yang dimilikinya.

8. Sikap dan situasi

Sikap seseorang terhadap suatu objek sering muncul dalam konteks situasi. Ini artinya situasi akan memengaruhi sikap konsumen terhadap suatu objek.

Menurut Grimm (dalam Sumarwan, 2012), tricomponent attitude model, sikap konsumen terdiri atas tiga komponen utama, yaitu berikut ini.

1. Komponen kognitif, terdiri atas pengetahuan dan persepsi yang didapat dari kombinasi pengalaman langsung dan informasi dari berbagai sumber.

2. Komponen afektif, merupakan emosi atau perasaan tentang suatu produk atau merek.

3. Komponen konatif, merupakan konsep sikap terkait dengan konsep keyakinan dan perilaku (behavioral) yang menggambarkan kecenderungan 
Kajian Sikap dan Perilaku Konsumen dalam Pembelian Kopi Serta Pendapatnya Terhadap Varian Produk dan Potensi Kedainya

ELLY R., PANDI P., HEPI H., RISYAD M.I., BOBBY R.S.

seseorang untuk melakukan tindakan tertentu yang berkaitan dengan objek sikap (produk atau merek tertentu).

\section{Perilaku Konsumen}

Perilaku konsumen adalah tindakan yang langsung terlibat dalam mendapatkan, mengkonsumsi, dan menghabiskan barang dan jasa, termasuk proses keputusan sebelum dan sesudah tindakan dilakukan (Engel, et al, 1995). Perilaku konsumen terbagi dua bagian, yaitu perilaku yang tampak dan perilaku yang tidak tampak. Variabel-variabel perilaku yang tampak antara lain jumlah pembelian, waktu pembelian, karena siapa, dengan siapa, dan bagaimana konsumen melakukan pembelian. Variabel perilaku yang tidak tampak adalah persepsi, ingatan terhadap informasi dan perasaan kepemilikan konsumen (Umar, 2000).

\section{Theory of Reasoned Action Model oleh Fishbein}

Model Fishbein memiliki dua komponen (Umar, 2005), yaitu berikut ini.

\section{Komponen sikap}

Komponen ini bersifat internal individu, berkaitan langsung dengan objek penelitian dan atribut-atribut langsungnya yang memiliki peranan penting dalam ukuran perilaku karena akan menentukan tindakan apa yang akan dilakukan, dengan tidak dipengaruhi faktor eksternal.

2. Komponen norma subjektif

Komponen ini bersifat eksternal individu yang berpengaruh terhadap perilaku individu. Komponen ini dapat dihitung dengan cara mengalikan antara nilai keyakinan normatif individu terhadap atribut dengan motivasi bersetuju terhadap atribut tersebut.

\section{Theory of Reasoned Action Model}

Ajzen dan Fishbein (Sumarwan, 2011) mengembangkan Theory of Reasoned Action. Dalam model ini yang dinilai adalah sikap terhadap perilaku atau $(\mathrm{Ab})$. Sikap seorang konsumen terhadap suatu objek seringkali tidak terkait secara kuat dengan perilakunya. Perilaku tertentu dari seorang konsumen sering ditentukan intensi atau kecenderungan atau keinginan yang kuat dari konsumen untuk melakukan perilaku tertentu. Atas dasar itu, Ajzen dan Fishbein membangun model atau mengembangkan model multiatribut sikap yang menghubungkan antara kepercayaan dan sikap konsumen dengan kecenderungan (intention) perilaku. 
Jurnal Pemikiran Masyarakat Ilmiah Berwawasan Agribisnis. 2017. 3(2): 117-133

\section{METODE PENELITIAN}

\section{Objek dan Tempat Penelitian}

Objek penelitian mengenai sikap dan perilaku konsumen terhadap pembelian produk di Armor Kopi.

Konsumen dalam penelitian ini adalah konsumen yang sedang membeli produk kopi di Armor Kopi. Tempat penelitian bertempat di Jl. Legok Randu, Dago, Bandung dengan alasan Armor Kopi memiliki lokasi yang merupakan wilayah kafe-kafe di Bandung. Alasan lainnya adalah Armor Kopi memiliki spesialisasi di bidang manual brewing / seduh manual serta jenis kopi yang beragam. Lokasi Armor Kopi juga merupakan daerah wisata yang memiliki suasana yang cukup menarik untuk di kunjungi.

\section{Definisi Variabel Penelitian}

Variabel penelitian meliputi :

1) Demografis Konsumen, terdiri atas: Usia, Jenis kelamin, Pendidikan, Pendapatan dan Domisili.

2) Sikap adalah penilaian yang baik atau tidak baik, perasaan emosional dan kecenderungan berbuat yang bertahan selama waktu tertentu terhadap suatu objek. Berdasarkan teori Ajzen \& Fishbein mengenai attitude towards object konsep sikap konsumen diukur melalui Atribut Produk yang terdiri dari beberapa sub dimensi yaitu: Rasa, Variasi menu, Gaya dan desain produk, Layanan pelengkap, Harga dan Promosi.

3) Perilaku Konsumen adalah tindakan yang langsung terlibat dalam mendapatkan, mengkonsumsi, dan menghabiskan barang dan jasa, termasuk proses keputusan sebelum dan sesudah tindakan dilakukan (Engel, et al, 1995). Perilaku konsumen diantaranya: Alasan berkunjung, Frekuensi kedatangan, Dengan siapa berkunjung, Waktu pembelian, Biaya yang dikeluarkan, Persepsi dan Rasa Kepemilikan.

\section{Sampel Penelitian}

Populasi dari penelitian ini adalah pengunjung Armor Kopi seminggu yang berjumlah rata-rata berdasarkan sumber adalah 1.750 orang. Responden atau sampel yang dipilih adalah konsumen yang berkunjung dan sedang membeli kopi di Armor Kopi. Metode pemilihan sampel yang digunakan dalam penelitian ini adalah probability sampling dengan teknik sistematic sampling sedemikian rupa sehingga didapatkan jumlah respnden sebanyak 95 orang.

Pencarian data dilakukan dalam waktu seminggu dan proporsional. 
Kajian Sikap dan Perilaku Konsumen dalam Pembelian Kopi Serta Pendapatnya Terhadap Varian Produk dan Potensi Kedainya

ELLY R., PANDI P., HEPI H., RISYAD M.I., BOBBY R.S.

Pemilihan responden lebih banyak pada hari Sabtu dan Minggu mengingat pada saat tersebut jumlah kunjungan lebih banyak dari hari lainnya. Pemilihan responden mengikuti angka kelipatan 10 pada hari Senin sampai Jumat, dan kelipatan 5 pada hari Sabtu dan Minggu. Sehingga pemilihan responden hari Senin dan Jumat adalah pengunjung ke- 1, 11, $21,31, \ldots \ldots ., 91$ sampai berjumlah 10 orang per harinya. Pemilihan responden pada hari Sabtu dan Minggu adalah pengunjung ke- $1,6,11,16,21$, $26, \ldots \ldots . ., 106$ sampai berjumlah 22 orang per harinya. Semua pemilihan angka awal pengunjung dilakukan secara acak.

\section{Rancangan Analisis Data}

\section{Analisis Deskriptif}

Analisis deskriptif dalam penelitian ini digunakan untuk menggambarkan profil responden yang berkunjung ke Armor Kopi dengan cara melakukan tabulasi data reponden secara umum. Data profil responden akan dideskripsikan dan dilakukan perhitungan secara manual dengan bantuan kalkulator/komputer sehingga dapat dipahami. Analisis deskriptif juga digunakan untuk menggambarkan apa saja potensi dan kendala yang dimiliki oleh Armor Kopi.

\section{Theory of Reactioned Action}

Langkah pengukuran ini dilakukan seperti dalam mengukur sikap konsumen. Teori tindakan yang beralaskan gambaran pengintegrasian komponen-komponen sikap secara menyeluruh ke dalam struktur yang dimaksudkan untuk menghasilkan penjelasan yang lebih baik maupun peramalan yang lebih baik mengenai perilaku (Schiffman dan Kanuk, 2000). Model teori Reasoned Action digambarkan dengan formula (Kristianto, 2011):

$\mathrm{B} \sim \mathrm{BI}=\mathrm{W} 1(\mathrm{Ab})+\mathrm{W} 2(\mathrm{SN})$

Untuk menunjukkan bagaimana sikap konsumen dan perilaku konsumen terhadap produk yang dimiliki Armor Kopi digunakan metode statistika deskriptif berdasarkan model multiatribut fishbein. Data yang diperoleh dan dikumpulkan kemudian dianalisis berdasarkan model yang diterapkan, dengan tujuan untuk mengetahui bagaimana sikap dan perilaku konsumen terhadap produk Armor Kopi.

Dalam penelitian ini, skala perhitungan yang digunakan adalah Skala Likert. Skala Likert digunakan untuk mengukur sikap, pendapat dan persepsi seseorang atau sekelompok orang tentang fenomena sosial. Dalam penelitian, fenomena sosial ini telah ditetapkan 
Jurnal Pemikiran Masyarakat Ilmiah Berwawasan Agribisnis. 2017. 3(2): 117-133

secara spesifik oleh peneliti, yang selanjutnya disebut sebagai variabel penelitian (Sugiyono, 2011).

Dengan menggunakan Skala Likert, maka variabel yang akan diukur, dijabarkan menjadi sub variabel kemudian sub variabel dijabarkan lagi menjadi indikator-indikator yang dapat diukur. Akhirnya indikator-indikator yang terukur ini dapat dijadikan titik tolak untuk membuat item instrumen yang berupa pertanyaan atau pernyataan yang perlu dijawab oleh responden (Riduwan dan Kuncoro, 2008).

Jawaban setiap pertanyaan kuisioner/item instrumen yang menggunakan Skala Likert mempunyai gradasi dari sangat positif sampai sangat negatif yang dapat berupa kata-kata dari sebuah pernyataan atau pertanyaan. Dalam penelitian ini pengukuran digolongkan kedalam empat kategori yaitu:

Tabel 1. Skoring Variabel dengan Skala Likert

\begin{tabular}{cll}
\hline Skor & $\begin{array}{c}\text { Respon } \\
\text { Kualitatif }\end{array}$ & \multicolumn{1}{c}{ Indikator } \\
\hline 1 & $\begin{array}{l}\text { Sangat tidak } \\
\text { setuju }\end{array}$ & Sangat negatif \\
\hline 2 & Tidak setuju & Negatif \\
\hline 3 & Setuju & Positif \\
\hline 4 & Sangat setuju & Sangat Positif \\
\hline
\end{tabular}

Atribut produk dan kelompok preferensi yang akan dianalisis diukur menggunakan skala Likert empat angka. Atribut produk tersebut kemudian dilakukan analisis tingkat kepercayaan dan evaluasi, dengan tujuan untuk mengetahui kecenderungan atribut yang menyebabkan perilaku pembelian terjadi menurut responden. Kelompok preferensi juga dilakukan analisis tingkat keyakinan normatif dan motivasi, dengan tujuan untuk mengetahui kecenderungan kelompok preferensi yang menjadi tokoh panutan bagi responden dalam membeli produk. Sikap konsumen terhadap pembeian di Armor Kopi diperoleh berdasarkan hasil persentase perilaku terhadap atribut-atribut berdasarkan prioritas yang diberikan oleh responden. Sendangkan nilai perilaku diperoleh berdasarkan hasil presentase dari siapa dan sejauhmana responden membeli produk di Armor Kopi. Langkah selanjutnya, hasil skor sikap terhadap perilaku dan perilaku konsumen diintepretasikan berdasarkan rentang skor. Rumus yang digunakan adalah sebagai berikut:

Skala Interval $=\frac{(n-m)}{b}$

Dimana:

$\mathrm{m}$ : merupakan data tertinggi yang mungkin terjadi

$\mathrm{n}$ : merupakan data terendah yang mungkin terjadi

b : jumlah skala penilaian yang ingin dibentuk 
Kajian Sikap dan Perilaku Konsumen dalam Pembelian Kopi Serta Pendapatnya Terhadap Varian Produk dan Potensi Kedainya

ELLY R., PANDI P., HEPI H., RISYAD M.I., BOBBY R.S.

Hasil skor total sikap dan perilaku dihitung berdasarkan rumus sikap dan perilaku seperti di atas. Selanjutnya dihitung rata-rata dari sikap total dan perilakunya. Perhitungan dilakukan secara parsial (masing-masing) antara sikap $\mathrm{Ab}$ dan perilaku SN, selanjutnya hasil perhitungan akan di jelaskan secara deskriptif.

\section{HASIL DAN PEMBAHASAN}

\section{Karaktersitik Konsumen}

Terdapat lebih banyak konsumen laki-laki dibandingkan perempuan. Lebih banyaknya konsumen laki-laki yang membeli kopi di kedai kopi Armor sesuai dengan penelitian dari Riswan (2013) bahwa minum kopi biasanya didominasi oleh pria. Kemudian, konsumen yang berkunjung ke Armor Kopi Garden didominasi oleh konsumen yang berumur antara 20-30 tahun. Menurut Depkes RI (2009), usia 17-25 tahun tergolong masa remaja akhir dan usia 26-35 tahun tergolong masa dewasa awal. Menurut Adi (2014), tren berkumpul di warung kopi, khususnya di kalangan kaum muda Asia tidak diragukan lagi dan lazim di seluruh wilayah. Konsumen Kedai Armor Kopi Garden dengan usia 20-30 tahun masih dapat digolongkan sebagai kaum muda yang mengikuti tren untuk berkumpul di kedai kopi.

Konsumen yang datang sebagian besar berstatus sebagai pelajar/ mahasiswa/i. Hal ini dikarenakan lokasi kedai Armor Kopi Garden dekat dengan lokasi restoran, wisata, dan tidak terlalu jauh dari lingkungan universitas, diantaranya Universitas Padjajaran Dipatiukur dan Institut Teknologi Bandung yang kurang lebih jarak dari sana ke Armor Kopi Garden dapat ditempuh sekitar 10 menit. Karena alasan tersebut juga sehingga mayoritas konsumen berpendidikan terakhir SMA.

Mayoritas responden dalam penelitian ini adalah konsumen dengan tipe kelas menengah dan tipe kelas atas dengan pendapatan Rp 1.000.000 - Rp 2.000.000 serta penghasilan lebih dari Rp 2.000.000 (Saraswati, 2009). Pendapatan sebagian besar responden di atas adalah karena mayoritas status dari responden adalah mahasiswa/i yang biasanya mereka berpendapatan sekitar Rp 1.000.000,- sampai dengan Rp 3.000.000,-.

Selanjutnya, domisili konsumen yang datang ke Armor Kopi Garden mayoritas adalah berasal dari dalam kota. Hal ini menunjukkan bahwa Armor Kopi Garden banyak dikunjungi oleh 
Jurnal Pemikiran Masyarakat Ilmiah Berwawasan Agribisnis. 2017. 3(2): 117-133

konsumen dari dalam bandung itu sendiri. Tidak sedikit juga konsumen dari luar kota yang datang ini menandakan Armor Kopi Garden yang cukup menarik konsumen dari dalam maupun luar kota Bandung. Konsumen dalam kota
(Bandung) memang lebih tahu dengan lokasi dari Armor Kopi Garden itu sendiri dibandingkan dengan responden dari luar kota karena lokasi yang sedikit terpencil dan tidak terlihat dari jalan utama.

Tabel 2. Karakteristik Konsumen Kopi di Armor Kopi Garden

\begin{tabular}{|c|c|c|c|}
\hline Karakteristik & Respon Variabel & Frekuensi & $\%$ \\
\hline \multirow[t]{2}{*}{ Jenis Kelamin } & Laki-Laki & 54 & 57 \\
\hline & Perempuan & 41 & 43 \\
\hline & Total & 95 & 100 \\
\hline \multirow[t]{3}{*}{ Umur } & $<20$ tahun & 12 & 13 \\
\hline & $20-30$ tahun & 82 & 86 \\
\hline & $>30$ tahun & 1 & 1 \\
\hline & Total & 95 & 100 \\
\hline \multirow[t]{5}{*}{ Perkerjaan } & Pelajar/Mahasiswa/i & 64 & 67 \\
\hline & Pegawai Negeri & 1 & 1 \\
\hline & Pegawai Swasta & 11 & 12 \\
\hline & Wiraswasta & 8 & 8 \\
\hline & Tidak/belum bekerja & 11 & 12 \\
\hline & Total & 95 & 100 \\
\hline \multirow[t]{4}{*}{ Pendidikan } & SMA & 56 & 59 \\
\hline & Akademi/Diploma & 4 & 4 \\
\hline & Sarjana/S1 & 34 & 36 \\
\hline & Pasca Sarjana & 1 & 1 \\
\hline & Total & 95 & 100 \\
\hline \multirow{3}{*}{$\begin{array}{l}\text { Pendapatan Per } \\
\text { Bulan }\end{array}$} & $<\mathrm{Rp} 1.000 .000$ & 21 & 22 \\
\hline & Antara Rp 1.000.001 S.d Rp 3.000.000 & 60 & 63 \\
\hline & $>\mathrm{Rp} 3.000 .001$ & 14 & 15 \\
\hline & Total & 95 & 100 \\
\hline \multirow[t]{2}{*}{ Domisili } & Dalam Kota (Bandung) & 55 & 58 \\
\hline & Luar Kota & 40 & 42 \\
\hline & Total & 95 & 100 \\
\hline
\end{tabular}

Sikap dan Perilaku Konsumen terhadap Pembelian di Armor Kopi Garden

Berdasarkan Tabel 3, sikap konsumen terhadap pembelian yang mereka lakukan di Armor Kopi Garden secara keseluruhan adalah tidak baik. Walaupun rata-rata tingkat kepercayaan konsumen terhadap atribut produk kopi yang dijual baik dan evaluasi akan atribut setelah mereka melakukan pembelian 
Kajian Sikap dan Perilaku Konsumen dalam Pembelian Kopi Serta Pendapatnya Terhadap Varian Produk dan Potensi Kedainya

ELLY R., PANDI P., HEPI H., RISYAD M.I., BOBBY R.S.

adalah puas, namun sikap terhadap perilaku pembelian mereka tidak baik.

Skor sikap terkecil ada pada sikap terhadap perilaku pembelian mereka yang didasari oleh atribut promosi yang menunjukkan hasil tidak baik. Hal ini menunjukkan pembelian yang dilakukan oleh konsumen tidak terlalu dipengaruhi oleh promosi yang dilakukan oleh Armor Kopi Garden. Pada penilaian keyakinan yang dilakukan oleh konsumen terhadap promosi menunjukkan hasil yang juga tidak baik. Menurut mereka pembelian yang dilakukan tidak didasari akan promosi yang dilakukan. Berdasarkan angka skor, mereka tidak yakin dan percaya promosi yang dilakukan oleh Armor Kopi Garden menarik.

Skor sikap tertinggi terdapat pada gaya dan design produk menandakan pembelian yang dilakukan memiliki sikap yang paling baik terhadap gaya dan design produk dari kopi yang disajikan oleh Armor Kopi Garden. Hal ini menunjukkan alasan paling baik konsumen membeli produk di Armor Kopi Garden karena gaya dan design produk kopinya. Cara pembuatan dan penyajian kopi di Armor Kopi Garden lah yang menurut konsumen menarik sehingga mereka suka untuk membeli kopi disana.

Tabel 3. Tingkat Kepercayaan Konsumen Terhadap Atribut Produk Kopi di Armor Kopi Garden

\begin{tabular}{|c|l|c|}
\hline No. & \multicolumn{1}{|c|}{ Atribut } & Keterangan \\
\hline 1 & Rasa & Baik \\
\hline 2 & Variasi Menu & Baik \\
\hline 3 & $\begin{array}{l}\text { Gaya dan design } \\
\text { produk }\end{array}$ & Baik \\
\hline 4 & $\begin{array}{l}\text { Layanan Pelengkap } \\
\text { (Consulting) }\end{array}$ & Baik \\
\hline 5 & Harga & Baik \\
\hline 6 & Promosi & Tidak Baik \\
\hline \multicolumn{2}{r|}{ Rata-Rata } & Baik \\
\hline
\end{tabular}

Alasan konsumen berkunjung ke Armor Kopi Garden mayoritas konsumen beralasan lokasi yang nyaman lah yang menjadi alasan mereka berkunjung. Armor Kopi Garden memang memiliki suasana yang nyaman karena tempat yang sering dijadikan tempat untuk berkumpul atau nongkrong para konsumennya. Lokasi yang tidak dekat keramaian kota, sejuk dan juga fasilitas tambahan seperti wifi dan lainnya membuat Amor Kopi Garden nyaman untuk dikunjungi.

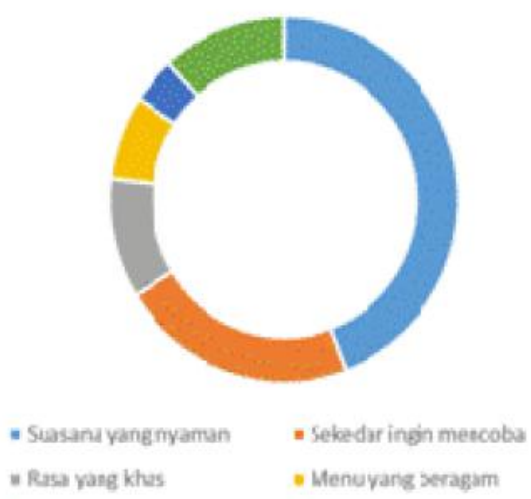

Gambar ${ }^{\text {ancol }}$ 3. ${ }^{\text {thoof }}$ Alassan Responden Berkunjung ke Armor Kopi Garden 
Jurnal Pemikiran Masyarakat Ilmiah Berwawasan Agribisnis. 2017. 3(2): 117-133

Sumber: Data Primer, diolah (2017)

Potensi dan Kendala Armor Kopi Garden

Kedai Armor Kopi Garden merupakan salah satu kedai kopi berkonsep manual brewing yang ada di Bandung. Ditambah dengan fasilitas yang Armor kopi berikan dan lokasi yang terbilang nyaman membuat kedai ini ramai didatangi pengunjung. Nama "Armor" diambil dari singkatan "Arabica Multi Origin”, ini merupakan salah satu ciri khas dari kedai kopi Armor yang menjual beragam jenis kopi dari seluruh nusantara.

Setidaknya ada 140 jenis beans kopi yang dijual disana, sehingga konsumen dapat merasakan variasi jenis beans kopi yang beragam. Semua jenis beans kopi yang dijual semua adalah olahan dari Armor Kopi itu sendiri dari green beans hingga men-roast atau menyangrai beans dilakukan oleh pihak Armor Kopi, yaitu pak Willy selaku pengelola dapur dan juga beans kopi disana.

Selain jenis kopi yang beragam, keragaman alat yang dimiliki oleh Armor Kopi itu sendiri juga menjadi ciri khas dari kedai kopi ini. Alat-alat manual brewing yang ada menciptakan keunikan dari tiap rasa kopi yang disajikan. Konsumen dapat memilih sendiri alat apa yang akan digunakan oleh barista untuk membuat kopi yang dipesannya. Konsumen juga dapat membeli langsung roasted beans, green beans yang ada di sana baik dalam bentuk beans maupun grinded beans atau kopi yang sudah berbentuk bubuk.

Konsumen tidak hanya dimanjakan dengan sajian kopi saja disana melainkan suasana yang ada seperti wifi, tv, musik, dan suasana alam sehingga konsumen dapat melakukan aktifitas berkumpul, rapat dan lainnya dengan nyaman. Walaupun untuk lokasi tidak seperti kedai kopi Armor yang berada di Tahura, kedai kopi Armor Garden yang berlokasi di Legok Randu memiliki susasana yang lebih private dan tidak terlalu ramai dengan hiruk pikuk pengunjung lain karena hanya berdiri sendiri tanpa ada kedai atau toko lain di sekitarnya. Kedai Armor Kopi Garden juga sering digunakan untuk berkumpul beberapa komunitas kopi di Bandung untuk sharing mengenai kopi.

Sumber daya manusia atau pekerja yang digunakan di Armor Kopi Garden ini berjumlah 8 orang, diantaranya 4 barista, 2 service, dan 2 disher yang kadang merangkap menjadi cashier. Semua karyawan yang menjadi barista terlebih dahulu berposisi sebagai disher 
Kajian Sikap dan Perilaku Konsumen dalam Pembelian Kopi Serta Pendapatnya Terhadap Varian Produk dan Potensi Kedainya

ELLY R., PANDI P., HEPI H., RISYAD M.I., BOBBY R.S.

lalu service dan terakhir ditraining untuk menjadi barista. Pembagian waktu kerja pun terbagi menjadi dua, yaitu shift pagi sampai sore dan shift sore hingga malam hari.

Pesaing yang dimiliki oleh kedai Armor Kopi Garden itu sendiri adalah kedai Armor Kopi yang berada di Tahura. Menurutnya lokasi yang terbilang baru dan terbilang dekat membuat konsumen terbagi dan lebih mengenal Armor Kopi berada di Tahura.

\section{PENUTUP}

Karakteristik konsuman yang datang ke Armor Kopi Garden lebih banyak yang berjenis kelamin laki-laki dari pada perempuan, berumur antara 21 sampai 30 tahun, berstatus pelajar, mahasiswa/i, dan berpendidikan akhir SMA, berpendapatan antara Rp1.000.000,- sampai Rp 3.000.000,- , dan berasal dari kota Bandung.

Sikap konsumen di Armor Kopi Garden secara kesuluruhan menunjukkan hasil tidak baik. Skor sikap per atribut menunjukkan promosi dan layanan pelengkap (consulting) dengan skor hasil tidak baik, namun sikap konsumen terhadap rasa, variasi menu, gaya dan design produk, dan harga menunjukkan skor hasil baik.
Perilaku konsumen di Armor Kopi Garden secara keseluruhan menunjukkan hasil tidak baik. Skor perilaku konsumen per kelompok preferensi menunjukkan keluarga, media, dan penjual dengan hasil tidak baik, namun pada kelompok preferensi teman menunjukkan hasil baik sehingga keluarga, media, dan penjual tidak terlalu mempengaruhi permbelian konsumen di Armor Kopi Garden melainkan teman dari konsumen lah yang paling mempengaruhi pembelian di Armor Kopi Garden.

Potensi dari Armor Kopi Garden yang terdiri fasilitas yang lengkap dan nyaman, lokasi yang nyaman dan lebih private, kelengkapan alat yang beragam dan lengkap, sumber daya manusia yang dilatih, dan produk yang beragam yang dimiliki membantu dalam menjalankan usahanya. Namun terdapat kendala dari pesaing yaitu Armor Kopi Tahura yang walaupun masih satu kepemilikan namun hal tersebut membuat konsumen yang datang terbagi dan lebih memilih Armor Kopi Tahura dibandingkan Armor Kopi Garden yang lokasinya memang tidak terlalu jauh.

\section{DAFTAR PUSTAKA}

Asosiasi Eksportir Kopi Indonesia. 2010. Sejarah Kopi di Indonesia. Diakses 
Jurnal Pemikiran Masyarakat Ilmiah Berwawasan Agribisnis. 2017. 3(2): 117-133

dari www.aeki-aice.org. (diakses pada Maret 2016)

Atamawinata. 2007. Asosiasi Eksportir Kopi Indonesia. Jakarta. Diakses pada www.aeki-aice.org. (diakses pada Febuari 2016)

Damanik, Anita Magdalena. 2008. Analisis Sikap dan Preferensi Konsumen terhadap Coffee Shop De Koffie - Pot Bogor. Skirpsi. Jurusan Ilmu-ilmu Sosial Ekonomi Pertanian. Fakultas Pertanian. Institut Pertanian Bogor. Bogor

Depkes RI. 2009. Sistem Kesehatan Nasional. Jakarta

Eagly, A. H. \& Chaiken, S. 1993. The Psychology of Attitudes. Fort Worth, TX: Harcourt Brace Jovanovitch.

Engel, J.F., R.D. Blackwell dan P.W. Miniard. 1995. Perilaku Konsumen. Edisi Keenam. Jilid 1 \& 2. Jakarta: Binarupa Aksara.

Euromonitor. 2015. Cafe and Bars in Indonesia. Diakses dari www.euromonitor.com. (diakses pada April 2016).

Fishbein dan Ajzen, 1975. Belief, Attitude, Intentions and Behavior: an introduction to theory and research. California: AddisonWesley Publishing Company, Inc.
Husein Umar, 2005. Metode Penelitian. Jakarta: Salemba Empat Indriani. 2006. Buku Favorit ala Cafe. Jakarta. Gramedia Pustaka Utama. Mariana. A. 2004. Analisis Proses Keputusan Pembelian Konsumen ke Kafe Victoria, Cilandak Town Square. Skripsi. Jurusan Ilmu-ilmu Sosial Ekonomi Pertanian. Fakultas Pertanian. Institut Pertanian Bogor. Bogor.

Riduwan dan Kuncoro, 2008. Cara Menggunakan dan Memakai Analisa Jalur. Bandung: Alfabeta.

Satria. Adi, 2014, Warung Kopi: Gaya Hidup atau?, Diakses dari www.kompasiana.com (diakses pada Agustus 2016)

Schiffman, Leon G., \& Leslie Lazar Kanuk. 2000. Consumer Behaviour 7th Edition., Prentice Hall: International

Soetarno, R. 1994. Psikologi Sosial. Yogyakarta: Kanisius

Sugiyono. 2011. Metode Penelitian Kuantitatif, Kualitatif, dan $R \& D$. Bandung: Alfabeta.

Umar, Husein. 2005. Riset Pemasaran \& Perilaku Konsumen. Jakarta: PT SUN. 